\title{
Microbiological screening of street-vended groundnut cake, Kulikuli and natural spices for reducing microbial contamination in the food snack
}

\author{
Femi AYOADE* and Temitope Dharma ADEGBITE \\ Department of Biological Sciences, College of Natural Sciences, Redeemer's University PMB 230, Ede, \\ Osun State, Nigeria. \\ "Corresponding author; E-mail: ayoadef@run.edu.ng
}

\begin{abstract}
Groundnut (Arachis hypogea) and its popular derivative snack-product, kulikuli are particularly prone to contamination by a wide variety of toxigenic microorganisms due to its high nutritive content. Peanuts are rich in calories and contain many nutrients, minerals, antioxidants, and vitamins that are essential for optimum health. Samples were collected from five selected sites within the Mowe market, Ogun State, South-West Nigeria from two experimental blocks and compared for microbial quality with laboratory-prepared samples treated with plant-derived natural spices. Aliquots of diluents of the treatments were inoculated in duplicates onto Eosin Methylene Blue (EMB) agar and Potato dextrose agar (PDA) to screen for coliform bacteria and fungi respectively to obtain the total colony count (TCC). The bacterial species isolated from the market samples include Serratia fonticola, Proteus vulgaris, while Morganella morganii and Proteus vulgaris were isolated from laboratory samples. Conversely, Rhizopus nigricans, Penicilium nigricans, Mucor hiemalis, Alternaria alternata and Aspergillus niger are the fungal organisms isolated from the market and laboratory samples. The result of the total bacterial count (TBC, cfu/ml) show that the market samples displayed the highest TBC when compared with laboratory-prepared samples treated with natural spices, even better than the preservative chemical (sodium benzoate) treated samples. The cinnamon treated samples showed the lowest TBC values. The results confirmed that treating kulikuli with spices may reduce the effect of toxigenic organisms associated with this food product.
\end{abstract}

(C) 2016 International Formulae Group. All rights reserved.

Keywords: Enterotoxigenic, Aflatoxin, kulikuli, Natural spices, Enterobacteriacae.

\section{INTRODUCTION}

Peanut cake (Kulikuli) is a snack delicacy indigenous to the West African coast. Kulikuli is usually produced from groundnut during groundnut oil extraction and then fried to obtain the final product (Adjou et al., 2012). Apart from being a part of the diet of most age ranges, peanut cake is most commonly consumed by the middle aged and younger persons, particularly students. Peanuts and its derivatives are often classified as street food which satisfies essential need of the urban population by being affordable and available (Boli et al., 2014). It is also used as a major ingredient in the production of poultry feed formulation (Ademola et al., 2015). 
Kulikuli is rich in protein and crude fat similar to its parent material, groundnut (Aletor and Ojelabi, 2007; Kolapo et al, 2012; Ejoh and Ketiku, 2013).

Groundnut or Peanut (Arachis hypogea Linn) is a plant which belongs to the family Fabaceae (Eke-Ejiofor et al., 2012). Botanically, groundnut is a legume although it is widely identified as a nut and has similar nutrient profile with tree nuts (Ros, 2010). This annual plant is generally distributed in the tropical, sub-tropical and temperate regions and represents the second most important legume in the world based on total production after soybean (Redden et al., 2005). The main producing countries are China, India, Nigeria, United States, Indonesia and Sudan (Okaka 2005).

When the basic composition per $100 \mathrm{~g}$ groundnut is compared with that of other nuts it is found to contain more plant protein than any other legumes or nuts (Settaluri et al., 2012; Sibt-e-Abbas et al., 2015). Moreover, groundnut is often referred to as a poor man's protein due to its availability and affordable prices. Due to its high nutritive content, peanut cake in Nigeria is prone to contamination by a wide variety of microorganisms including many bacterial species ranging from the simple commensals to the pathogenic types and fungal organisms (Ezekiel et al., 2014). Contamination by these microorganisms occurs during handling, storage and transportation as a result of improper processing and storage conditions, thereby exposing groundnut and its products to the risk of contamination with aflatoxin (Polixeni and Panagiota, 2008; Mutegi et al., 2012). Among the bacterial contaminants are the enterobacteriaceae, a group of Gramnegative intestinal bacteria that are extremely pathogenic to man and animals (Cox and Pavic, 2010). Also, amongst these are notable enterotoxigenic pathogens such as Escherichia coli, Salmonella, Shigella and Klebsiella, and multidrug resistant (MDR) strains of these organisms (Esimone et al., 2010; Ezekiel et al., 2011).

Mycotoxins are secondary metabolites of fungal origin which produce toxic responses when ingested by animals or humans. Mycotoxicosis is a term used to denote the diseases that result from the ingestion of mycotoxin by animals and humans (Frisvard et al., 2007). Most mycotoxins of concern are produced by three genera of fungi, namely, Aspergillus, Penicillium, and Fusarium. These are the predominant fungal genera associated with food grains during storage (Richard et al., 2003). These organisms grow in groundnuts when the moisture content exceeds $9 \%$ and has optimum growth conditions of between 25 and $30{ }^{\circ} \mathrm{C}$, and water activity of 0.99 with a minimum of 0.83 , while production of aflatoxin occurs optimally at $25{ }^{\circ} \mathrm{C}$ and water activity of 0.99 (Ribeiro et al., 2006). Certain Agricultural produce have been observed to permit the growth of some moulds over others. For example, maize allows the growth of aflatoxins and fumonisins producing moulds above others, while groundnuts have been found to be excellent substrate for aflatoxin contamination (Bankole and Adebanjo, 2003).

The expression of mycotoxins on food materials is known to vary depending on the presence of other bacterial or fungal microorganisms. For example, when Aspergillus parasiticus was grown in the presence of some bacteria such as Streptococcus lactis and Lactobacillius casei, aflatoxin production was reduced (Cousin et al., 2005). However, this does not prevent the bacterial organisms from expressing their own undesirable effects such as bad odor, throat infections and tooth caries. Meanwhile, fungal metabolites such as rubratoxins from Penicillium purpurogenum; cerulenin from Ephalosporium caerulens and Acrocylindrium oryzae enhance aflatoxin production even though they repress growth of aflatoxin- 
producing fungi (Atanda et al., 2013). This type of positive interaction between fungi in the same food matrix with regards to aflatoxin synthesis coupled with multi-occurrence of mycotoxins from the different fungi could have additive or synergistic effect on the health of the host (Speijer and Speijer, 2004; Li et al., 2014) and worsen the aflatoxin plight in Nigeria (Atanda et al., 2013).

Plant products such as spices have been used not only to provide flavor and aroma in foods but also for their antimicrobial properties. The antimicrobial activities of plant-derived natural spices against different types of microbes, including food borne pathogens is well documented (Ayoade et al., 2012; Okorondu et al., 2012; Agbebi et al., 2013; Panpatil et al., 2013; Bag and Chattophadhyay, 2015). It has been reported that spices owe their antimicrobial properties mostly to the presence of alkaloids, phenols, glycosides, steroids, essential oils, coumarins and tannins (Cherrat et al., 2014). For example, the extract of traditional natural spices such as garlic have been shown to have a broad spectrum antibacterial activity, including effects on Escherichia, Salmonella, Staphylococcus, Streptococcus, Klebsiella, Proteus, Clostridium, Mycobacterium and Helicobacter species (Benkeblia, 2004; Goncagul and Ayaz, 2010; Nejad et al., 2014).

Co-infestation of food products by mycotoxigenic fungi with many bacterial species and strains of the Family Enterobacteriacae which are known to be enterotoxigenic contribute a major quota to the many diarrheal illnesses in humans, and it is a serious economic, health and food safety control issue in sub-Saharan Africa (Atanda et al., 2013). The present work was aimed at screening Kulikuli samples obtained from various locations in Mowe Metropolis, in Ogun State, Nigeria for the presence of these noxious organisms. Mowe metropolis is located on the Lagos-Ibadan expressway, perhaps the busiest road in West Africa. It is made up by other towns apart from Mowe including Ofada, OPIC, Loburo, Redemption Camp and so on. Mowe metropolis is second only to the Ogun state capital, Abeokuta in terms of business activities and population (Ajayi, 2015).

The present work was aimed at evaluating street-vended kulikuli in the sampled location for microbial quality when compared with laboratory-prepared samples treated with plant-derived natural spices. The objective was to screen these natural spices for effectiveness at reducing the microbial load in kulikuli, thereby minimizing the risk of food poisoning by the contaminants.

\section{MATERIALS AND METHODS}

\section{Study site}

Using a completely randomized block sampling method, samples were collected from five selected sites within the Mowe market, Ogun state, South-west Nigeria. Mowe market is a full-time commercial environment where people buy and sell different commodities, ranging from food stuffs to provisions, clothes, foot wears, auto spare parts and so on. The samples were obtained from five different locations. The five sampling locations were classified as "street hawker" or "vendor". The street hawkers put their wares in wheel barrows as they move around the market; although the peanut cakes are put in jute-sacks they are exposed to dust and fumes from the combustion of vehicles and motorcycles. On the other hand, the vendors put their wares in sacks but are restricted to their shops with the goods covered with thin sacks so as to allow air passage within the sack. Samples were obtained from three different locations from the sources classified as "street hawkers" while samples were obtained from two locations classified as "vendor". The microorganisms isolated from the street hawkers samples were coded as $\mathrm{SH} 1, \mathrm{SH} 2$ 
and SH3 while those from vendor samples were coded as V1, and V2.

\section{Laboratory preparation of kulikuli stock}

$600 \mathrm{~g}$ of shelled peanut was sorted roasted and ground. Oil was extracted from the ground peanut seeds in a previously heatsterilized mortar and pestle by adding hot sterile distilled water. After the oil removal process was repeated severally, the final paste was then used as stock in preparing the chemical preservative (Sodium benzoate) and natural spices-treated samples. A flow chart of the kulikuli preparation process is shown in Chart 1.

\section{Laboratory preparation of chemical preservative and natural spice-treated kulikuli}

For the spice treatments, the natural spice to be used (i.e., onion, garlic, cinnamon and nutmeg) were grated using a clean grater and $100 \mathrm{~g}$ of each spice was added to each bowl according to their labels to give $1 \% \mathrm{w} / \mathrm{v}$ concentration per spice. For the chemical preservative treatment, sodium benzoate at different concentrations ( $1 \%$ and $0.1 \%$ ) was applied and a control to which no preservative was added.

\section{Microbiological analysis}

$100 \mathrm{mg}$ of each kulikuli sample was aseptically transferred into a sterile test tube containing $9 \mathrm{ml}$ of sterile water, thoroughly shaken using a vortex and serially diluted up to $10^{-9}$ dilution. $1 \mathrm{ml}$ of dilutions $10^{-2}, 10^{-5}$, $10^{-9}$ was inoculated in duplicates onto Eosin Methylene Blue (EMB) agar and Potato dextrose agar (PDA) for bacteria and fungi respectively, the EMB plates were incubated at $37{ }^{\circ} \mathrm{C}$ for 24 hours and the PDA plates at $30{ }^{\circ} \mathrm{C}$ for 3-6 days before reading the plates. EMB agar was used to screen for members of the family Enterobacteriacae, the bacterial contaminants of interest. Pure cultures were obtained by re-streaking into Nutrient Agar (NA) employing standard methods. The bacteria isolates were identified based on shape, colony, color, and Gram's staining reactions and biochemical tests such as methyl red, Vogues-Praskauer, Citrate, Urease, Indole, Motility, Catalase, Oxidase, Lysine Decarboxylase and Sugar fermentation tests (Cheesbrough, 2006). The fungal samples were examined macroscopically on the plates and recorded. Morphological characteristics observed include colony appearance, type of colonies, colony color (surface and backside colors), hyphal structures, type of spores and other cultural characteristics (Watanabe, 2010). For microscopic examination, the fungal isolates were identified by placing a drop of cotton lactophenol blue on a clean slide. Using an inoculating needle, a small piece of mycelium free of medium was picked and transferred to stain on slide carefully and evenly dispersed. This was gently covered with a cover slip to avoid air bubbles, and then viewed under the microscope for cultural characterization (Watanabe, 2010).

\section{Sensory evaluation}

A randomly selected 25 member panel consisting of interested Redeemer's University students was used to evaluate the laboratory-prepared kulikuli. The panel tested the products by eating it, then rinsing their mouth with water after testing each product and ranked them on the basis of appearance, color, flavor, taste and overall acceptability on a 9- point hedonic scale. 9 = Like extremely; $8=$ Like very much; $7=$ Like moderately; $6=$ Like slightly; $5=$ Neither like nor dislike; $4=$ Dislike slightly; $3=$ Dislike moderately; $2=$ Dislike very much; $1=$ Dislike extremely. The participants in the sensory evaluation have tasted kulikuli at least more than ten times before participation in the tasting event was administered and as such are used to the widely acceptable taste of kulikuli. 


\section{Statistical analysis}

The Duncan's Multiple Range Test $(p \leq 0.05)$ was used to compare the mean Total Colony Counts for all the treatments in the microbial analysis of the field samples and the laboratory control. The raw scores obtained from the sensory evaluation were assembled and the mean scores were used to perform the Analysis of Variance (ANOVA). Independent $\mathrm{T}$ test was conducted to check for significant difference between the control kulikuli and other kulikuli samples.

\section{RESULTS}

A total of 74 distinct bacterial colonies were isolated from the entire study and were classified according to the sampling locations from which they were isolated, namely, "market samples" (MS), for samples that were obtained from the market and "laboratory samples" (LS) for samples obtained from kulikuli made in the laboratory. 57 and 17 of these distinct colonies were obtained from market and laboratory samples respectively. Based on cultural characteristics, two distinctly different colonies each were selected as representative organisms from the market and laboratory samples. As shown in Table 1, the representative samples were tagged and identified using morphological, cultural and biochemical methods as follows: MS-1 (Serratia fonticola), MS-2 (Proteus spp), LS-1 (Morganella morganii) and LS-2 (Proteus vulgaris).

As shown in Table 2, the highest number of bacterial isolates was found in "vendor" samples with 12 isolates recorded at each of the sampled sites followed in descending order by "street hawkers" samples and "Laboratory control" samples (to which no spices were added); Sodium benzoate treated; Nutmeg treated; Onion treated and Cinnamon treated samples. The lowest number of isolates was recorded for the cinnamon isolates where only 1 bacterial organism was isolated.
Bacteriological analyses of Mowe kulikuli samples yielded a total of 57 isolates from which two distinct organisms were identified and characterized. The two organisms were identified as Serratia fonticola and Proteus spp. Ninety five percent of this total of 57 isolates were identified as Serratia fonticola. This organism was found on all the samples from the different locations. On the other hand, Proteus spp was isolated from only one location at Street Hawker location 2 (Table 3).

Altogether, a total of 17 bacterial isolates were obtained from the analysis of kulikuli samples that were made in the laboratory and treated with natural spices and chemical preservatives in order to reduce microbial contamination. The results in Table 4 show that a general reduction in the number of organisms was found in the (chemically or natural spice) treated kulikuli samples when compared with the untreated control. From the untreated control, four bacterial organisms were isolated, however, none of the treated samples had up to four bacterial isolates in them (Table 4). Two distinct organisms were identified and characterized from the batch of bacterial isolates obtained from the laboratory prepared kulikuli; the two organisms were identified as Morganella morganii and Proteus spp. More than seventy five percent of this total of 17 isolates was identified as Proteus spp (Table 4).

The result of the total bacterial count (TBC, cfu/ml) from both the market and laboratory samples is shown in Table 5. Vendor- 1 (V-1) samples displayed the highest TBC when compared with all other samples followed by the SH-1, V-2, SH-3, $0.1 \%$ Sodium benzoate, SH-2, Laboratory control, $1 \%$ Sodium benzoate, Onion, Nutmeg and Cinnamon samples in descending order when compared using the Duncan's Multiple Range Test at $\mathrm{p} \leq 0.05$ (Tables 4 and 5).

A total of 83 distinct fungal colonies were isolated from the entire study, 47 and 36 
of these distinct colonies were obtained from market and laboratory samples respectively. As shown in Table 6, Vendor- 2 (V-2) samples displayed the highest colony count of fungal isolates when compared with all other samples followed by the SH-3, SH-1, V-1, SH-2, Cinnamon, $1 \%$ Sodium benzoate and Nutmeg in descending order. The lowest number of fungal isolates was recorded for the nutmeg isolates where four fungal organisms were isolated. From the total of 83 fungal isolates, five distinct organisms were identified, namely, Rhizopus nigricans, Penicilium nigricans, Mucor hiemalis, Alternaria alternata and Aspergillus niger (Table 7).

Results of the organoleptic evaluation of the various treatments of the laboratory samples revealed that the chemically treated kulikuli were assessed highest for overall acceptability with values of 7.53 and 7.13 for $0.1 \%$ and $1 \%$ Sodium benzoate respectively. These were higher than the overall acceptability value of 6.67 indicated for the laboratory control. The natural spices treatments, namely, cinnamon, nutmeg and onion were scored 5.67, 6.80 and 5.90 respectively for overall acceptability. Statistically, the $\mathrm{T}$ test results show no significant difference between the control and each of the other samples. However, nutmeg seems to be the most promising when compared with other spices for overall acceptability (Table 8). The result obtained from the two- way ANOVA conducted on the mean of all the parameter shows the $F$ statistical value of " 0 " (.), which can in no way be greater than the tabulated Critical $\mathrm{F}$ value of 3.41 so we conclude that there is no significant difference between the mean values of all the spices in all measurement parameter (Appearance, Color, Flavor, Taste, Overall acceptability). $T$ test was conducted to confirm the significant difference between the control and each of the other samples individually; the results show no significant difference between the control and each of the other samples. Although nutmeg seem to be the most promising when compared with other spices for overall acceptability.

Table 1: Identification table of bacterial isolates from both Mowe Samples and the Laboratory samples.

\begin{tabular}{|c|c|c|c|c|c|c|c|c|c|c|c|c|}
\hline 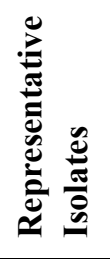 & 芯 & 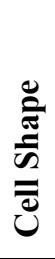 & 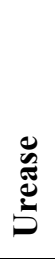 & $\begin{array}{l}\frac{0}{e} \\
\frac{\theta}{g}\end{array}$ & : & 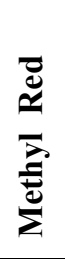 & 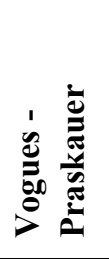 & 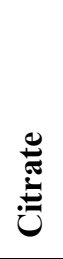 & 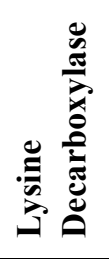 & $\stackrel{n}{=}$ & 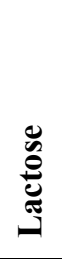 & 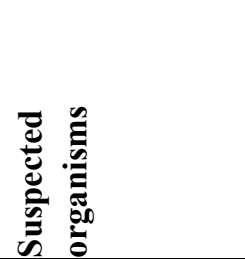 \\
\hline MS-1 & - & $\mathrm{C}$ & + & - & + & + & - & + & $+/-$ & - & + & $\begin{array}{l}\text { Serratia } \\
\text { fonticola }\end{array}$ \\
\hline MS-2 & - & $\mathrm{C}$ & + & - & + & + & - & + & + & - & + & Proteus spp. \\
\hline LS-1 & - & $\mathrm{C}$ & $\begin{array}{l}+1 \\
-\end{array}$ & + & $+/-$ & + & - & - & + & $-/+$ & - & $\begin{array}{l}\text { Morganella } \\
\text { morganii }\end{array}$ \\
\hline LS-2 & - & $\mathrm{C}$ & + & + & $+/-$ & + & - & - & - & $+/-$ & - & Proteus vulgaris \\
\hline
\end{tabular}


Table 2: Percentage occurrence of the bacterial isolates.

\begin{tabular}{lcc}
\hline Location & Number of isolates & Percentage (\%) \\
\hline SH-1* & $\mathbf{1 1}$ & $\mathbf{1 4 . 8}$ \\
SH-2 & $\mathbf{1 3}$ & $\mathbf{1 7 . 6}$ \\
SH-3 & $\mathbf{9}$ & $\mathbf{1 2 . 1}$ \\
V-1 & $\mathbf{1 2}$ & $\mathbf{1 6 . 2}$ \\
V-2 & $\mathbf{1 2}$ & $\mathbf{1 6 . 2}$ \\
Laboratory Control & $\mathbf{4}$ & $\mathbf{5 . 4}$ \\
Nutmeg treated & $\mathbf{3}$ & $\mathbf{4 . 1}$ \\
Cinnamon treated & $\mathbf{1}$ & $\mathbf{1 . 4}$ \\
Onion treated & $\mathbf{2}$ & $\mathbf{2 . 7}$ \\
0.1\% Sodium benzoate treated & $\mathbf{4}$ & $\mathbf{5 . 4}$ \\
1\% Sodium benzoate treated & $\mathbf{3}$ & $\mathbf{4 . 1}$ \\
Total & $\mathbf{7 4}$ & $\mathbf{1 0 0}$ \\
\hline${ }^{*}$ The microorganisms isolated from the street hawkers samples were coded as SH1, SH2 and SH3 while those from vendor \\
samples were coded as V1, and V2.
\end{tabular}

Table 3: Occurrence of bacterial isolates based on identified organisms from Mowe market Samples.

\begin{tabular}{lccc}
\hline Serial Number & Location & \multicolumn{2}{c}{ Number of isolates of the identified organisms } \\
\cline { 3 - 4 } & & $\begin{array}{c}\text { Serratia fonticola (\%) } \\
* *\end{array}$ & Proteus spp (\%) \\
\hline $\mathbf{1}$ & SH-1* & $11(19.3)$ & 0 \\
$\mathbf{2}$ & $\mathbf{S H - 2}$ & $9(15.8)$ & $3(5.2)$ \\
$\mathbf{3}$ & $\mathbf{S H - 3}$ & $12(21.1)$ & 0 \\
$\mathbf{4}$ & $\mathbf{V - 1}$ & $11(19.3)$ & 0 \\
$\mathbf{5}$ & $\mathbf{V - 2}$ & $11(19.3)$ & 0 \\
Total & 95 & 5 \\
\hline$*$ The microorganisms isolated from the street hawker samples were coded as SH1, SH2 and SH3 while those \\
from vendor samples were coded as V1, and V2. \\
**The percentages of the occurrence values are indicated in parentheses
\end{tabular}

Table 4: Percentage occurrence of bacterial isolates based on identified organisms from Laboratory samples treated with natural spices and chemical preservatives.

\begin{tabular}{lccc}
\hline Treatments & \multicolumn{2}{c}{ Organisms } \\
\cline { 2 - 4 } & $\begin{array}{c}\text { Morganella morganii } \\
\mathbf{( \% )}\end{array}$ & Proteus vulgaris (\%) & Total \\
\hline Onion & $0^{\mathrm{c}}$ & $17.7(3)^{\mathrm{a}^{*}}$ & 3 \\
Nutmeg & $5.9(1)^{\mathrm{b}}$ & $5.9(1)^{\mathrm{b}}$ & 2 \\
Cinnamon & $0^{\mathrm{c}}$ & $17.7(3)^{\mathrm{a}}$ & 3 \\
$\mathbf{0 . 1 \%}$ Sodium benzoate & $11.8(2)^{\mathrm{a}}$ & $5.9(1)^{\mathrm{b}}$ & 3 \\
$\mathbf{1 \%}$ Sodium benzoate & $5.9(1)^{\mathrm{b}}$ & $5.9(1)^{\mathrm{b}}$ & 2 \\
Control & 0 & $23.3(4)^{\mathrm{a}}$ & 4 \\
Total & $\mathbf{2 3 . 6}(\mathbf{4})$ & $\mathbf{7 6 . 4}(\mathbf{1 3})$ & $\mathbf{1 7}$ \\
\hline Data with similar alphabets are not significantly different using the Duncan's Multiple Range Test at $\mathrm{p}<0.05$ &
\end{tabular}

Data with similar alphabets are not significantly different using the Duncan's Multiple Range Test at $\mathrm{p} \leq 0.05$ 
Table 5: Total bacterial count (TBC) for Mowe market and laboratory samples.

\begin{tabular}{lcc}
\hline Locations/ Treatment & Total Bacteria count (cfu/ml) & Ranking \\
\hline SH-1* & $0.76 \times 10^{-5 \mathrm{a}^{* *}}$ & 2 \\
SH-2 & $1.18 \times 10^{-4 \mathrm{~b}}$ & 6 \\
SH-3 & $3.34 \times 10^{-4 \mathrm{~b}}$ & 4 \\
V-1 & $0.97 \times 10^{-5 \mathrm{a}}$ & 1 \\
V-2 & $0.53 \times 10^{-5 \mathrm{a}}$ & 3 \\
Nutmeg & $0.21 \times 10^{-4 \mathrm{~b}}$ & 10 \\
Onion & $0.84 \times 10^{-4 \mathrm{~b}}$ & 9 \\
Cinnamon & $0.21 \times 10^{-3 \mathrm{c}}$ & 11 \\
$\mathbf{0 . 1 \%}$ Sodium benzoate & $1.81 \times 10^{-4 \mathrm{~b}}$ & 5 \\
$\mathbf{1 \%}$ Sodium benzoate & $1.08 \times 10^{-4 \mathrm{~b}}$ & 8 \\
Laboratory Control & $1.13 \times 10^{-4 \mathrm{~b}}$ & 7 \\
\hline * The total colony count (TCC, cfu/ml) obtained from the street hawkers samples were coded as SH1, SH2 and SH3 \\
$\quad$ while those from vendor samples were coded as V1, and V2. \\
** Data with similar alphabets are not significantly different using the Duncan's Multiple Range Test at $\mathrm{p} \leq 0.05$.
\end{tabular}

Table 6: Identification of fungal samples.

\begin{tabular}{llc}
\hline Isolates & Morphological characteristics & Suspected organisms \\
\hline Isolate 1 & $\begin{array}{l}\text { Black mycelium, rough appearance, cream on } \\
\text { reverse plate. }\end{array}$ & Rhizopus nigricans \\
Isolate 2 & $\begin{array}{l}\text { Dark green mycelium, rough and clustered } \\
\text { appearance, light brown color on reverse plate. }\end{array}$ & Penicillium nigricans \\
Isolate 3 & $\begin{array}{l}\text { White mycelium, rough and clustered, cream on } \\
\text { reverse plate. }\end{array}$ & Mucor hiemalis \\
Isolate 4 & $\begin{array}{l}\text { White mycelium, rough and clustered, black on } \\
\text { reverse plate. } \\
\text { Orange/Yellow mycelium, rough, light } \\
\text { brown/yellow on reverse plate. }\end{array}$ & Alternaria alternata \\
Isolate 5 & Aspergillus niger \\
\hline
\end{tabular}

Table 7: Colony count of Fungal isolates from Mowe and Laboratory prepared samples.

\begin{tabular}{lcc}
\hline Location/ Treatments & Number of colonies & Identities of the isolates \\
\hline SH-1* & $1.0 \times 10^{2 \mathrm{a}^{* *}}$ & $\begin{array}{c}\text { Rhizopus } \text { nigricans, } \\
\text { Alternaria alternate, } \text { Mucor } \\
\text { hiemalis } \text { and } \text { Aspergillus } \\
\text { niger }\end{array}$ \\
SH-2 & $0.6 \times 10^{2 \mathrm{~b}}$ & $\begin{array}{c}\text { Rhizopus } \text { nigricans, } \\
\text { Penicilium nigricans } \text { and } \\
\text { Aspergillus } \text { niger }\end{array}$ \\
$\mathbf{V - 1}$ & $1.1 \times 10^{2 \mathrm{a}}$ & $\begin{array}{c}\text { Mucor hiemalis, } \text { Alternaria } \\
\text { alternata } \text { and } \text { Aspergillus } \\
\text { niger }\end{array}$ \\
$\mathbf{V - 2}$ & $0.8 \times 10^{2 \mathrm{a}}$ & $\begin{array}{c}\text { Penicilium nigricans, } \text { Mucor } \\
\text { hiemalis } \text { and } \text { Alternaria } \\
\text { alternata }\end{array}$ \\
\hline & $1.2 \times 10^{2 \mathrm{a}}$ & Rhizopus nigricans, Mucor \\
\hline
\end{tabular}


hiemalis and Aspergillus

niger

Onion $0.5 \times 10^{2 \mathrm{~b}}$

Alternaria alternate,

Aspergillus niger

Nutmeg

$0.4 \times 10^{2 \mathrm{c}}$

Cinnamon

$0.6 \times 10^{2 \mathrm{~b}}$

0.1\% Sodium benzoate

$0.5 \times 10^{2 \mathrm{~b}}$

$1 \%$ Sodium benzoate

$0.6 \times 10^{2 \mathrm{~b}}$

Laboratory Control

$0.6 \times 10^{2 \mathrm{~b}}$

Aspergillus niger

Aspergillus niger

Aspergillus niger

Aspergillus niger

Aspergillus niger

* The total bacteria count (TBC, cfu/ml) obtained from the street hawkers samples were coded as SH1, SH2 and SH3 while those from vendor samples were coded as V1, and V2.

** Data with similar alphabets are not significantly different

Table 8: Organoleptic test results conducted for the laboratory prepared Kulikuli.

\begin{tabular}{lllllll}
\hline S/N & Spices & Appearance & Color & Flavor & Taste & $\begin{array}{l}\text { Overall } \\
\text { Acceptability }\end{array}$ \\
\hline 1 & Garlic & 5.37 & 5.53 & 3.63 & 3.83 & 5.63 \\
2 & Cinnamon & 5.77 & 6.00 & 3.83 & 3.67 & 5.67 \\
3 & Nutmeg & 5.30 & 5.73 & 4.63 & 4.07 & 6.80 \\
4 & Onion & 7.16 & 5.80 & 5.10 & 4.37 & 5.90 \\
5 & 0.1\% Sodium & 5.47 & 5.87 & 4.63 & 5.20 & 7.53 \\
& benzoate & & & & & \\
6 & 1\% Sodium & 5.10 & 5.27 & 4.00 & 4.20 & 7.13 \\
& benzoate & & & & & 6.67 \\
\hline
\end{tabular}

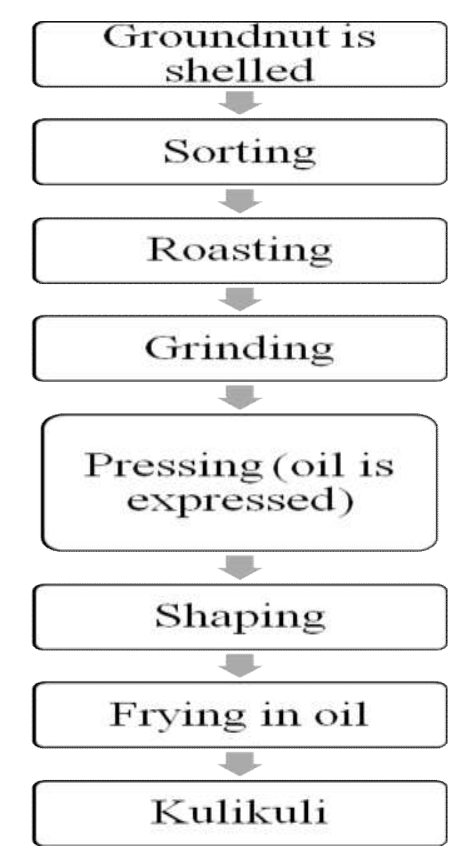

Chart 1: The Kulikuli Flow Chart. 


\section{DISCUSSION}

Results from the present study showed that kulikuli offered to the public in the sampled areas were heavily contaminated by aflatoxin producing fungi namely, Rhizopus nigricans, Penicilium nigricans, Mucor hiemalis, Alternaria alterna and Aspergillus niger including bacteria species of the Enterobacteriaceae family namely, Serratia fonticola, Proteus spp, Morganella morganii and Proteus vulgaris. This is consistent with results obtained elsewhere in previous studies (Ezekiel et al., 2011; Ezekiel et al., 2012; Adjou et al., 2012). Detection of members of the bacteria family Enterobacteriaceae in the present study underscores the public health importance of the poor quality of kulikuli in circulation in the sampled locations. Generally, the members of the family Enterobacteriacaeae are indicators of fecal contamination and have been implicated in several human infections (Hodge et al., 2016). Members of this bacterial family identified from the present study, namely, Serratia fonticola, Proteus spp, Morganella morganii and Proteus vulgaris are notorious for their ability to infect the human lower respiratory tract, causing serious diseases especially when antimicrobial susceptible strains are encountered (Wendel et al., 2013).

Considering the hygienic conditions under which the laboratory control samples in the present study were prepared, the four isolates from these samples are considerably high even when compared with the Street hawker/ vendor samples with an average of eleven isolates (Table 2). Moreover, a total bacteria count of $1.13 \times 10^{-4}$ was recorded for the control samples (Table 5). This confirms that the crop was already heavily infested with the aflatoxin producing organisms in the preprocessing stage. There is a need to determine the various points at which toxigenic organisms come in contact with groundnut from the field to the finished product and to institute means of controlling these organisms. In Nigeria, groundnuts and other crops are typically dried on the ground. Storage units are self-made and commodities are stored in piles without means of monitoring the temperature and humidity of such local storage units. These conditions encourage the multiplication of aflatoxin producing fungi and enteric bacteria with the attendant increased risk of exposure to aflatoxin and other poisons.

The use of contaminated water in the manufacturing of processed food in resourcepoor areas such as the present sample location has been reported (Mbaeyi-Nwaoha et al., 2012; Ayoade et al., 2013; Ogunyemi et al., 2015), However, results from the present study show that regardless of the microbiologically safe processing of the groundnut product in the laboratory by the use of sterilized distilled water and maintenance of standard hygiene procedures, there is only a marginal reduction in the level of contamination by aflatoxin producing microorganisms when compared with the field samples. These results indicate that not all the contamination of the finished product is ascribable to unhygienic processing of kulikuli but a major portion of the contamination has already occurred during the pre and postharvest, pre-processing stages of the groundnut.

Aflatoxin contamination in groundnuts is well above safe levels in Nigeria (Oladele, 2014). Published prevalence data from Nigeria suggests that aflatoxin contamination in groundnuts the parent crop from which kulikuli is derived is considerably higher than the European Union (EU) aflatoxin standard (4 ppb) or the U.S. standard (20 ppb). The mean level of aflatoxin contamination for groundnut in Africa including Nigeria ranges as high as 48,000 ppb (Jimoh and Kolapo, 2008; Odoemelam and Osu, 2009; Ezekiel et al., 2012). The hazard of aflatoxin contamination in groundnuts can be traced to the farm where pest infestation and subsequent infection by aflatoxin producing microorganisms initiate the process and the situation worsens at the post-harvest and storage stages. 
Previous reports indicating bacteriostatic and bactericidal effects of extracts and essential oils of natural spices appear to be well correlated with the results obtained in the present study. Tables 2, 4, 5 and 9 show the marked difference between the control, field and spice treated samples when compared for the occurrence of toxigenic microorganisms. In all cases, there were marked reductions in the occurrence of toxigenic organisms as a result of treatment with spices. For example, reports of antibacterial and antifungal activity of crude ethanolic extracts and essential oils of spices such as cardamom, cinnamon, clove, coriander, cumin, garlic, ginger, holy basil, onions, garlic, kaffir lime leaves and peels, lemongrass, mace, nutmeg, black and white pepper, and turmeric etc. against many serotypes of Salmonella and other species of enterobacteria may be found in literature (Burt, 2004; Tiwari et al., 2009; Tajkarimi et al., 2010). Moreover, antifungal activity of spices and derivatives has been studied regarding viable cells count, mycelia growth and mycotoxins synthesis. For example, reports of the effectiveness of crude extract and essential oils of natural spices such as clove, cinnamon and oregano to control the growth of mycotoxins producing moulds and to prevent the growth of noxious fungi such as Aspergillus parasiticus and Fusarium moniliforme and as such markedly reduce the aflatoxin synthesis in infected grains has been reported (Juglal et al., 2002; Benkeblia, 2004; Souza et al., 2005).

Results from the present study (Tables 2,4,5 and 7) show that the antimicrobial effects of the spices tested were achieved with minimal loses in organoleptic appeal as shown in Table 8. The results show that nutmeg presented the most marked antimicrobial activity, moreover, this particular spice also exhibited overall organoleptic acceptability approaching that of the control and even the salt (chemical) preservatives. In conclusion, there are promising edible natural spices that may be used in controlling mycotoxigenic moulds and enterotoxigenic bacteria associated with kulikuli, the groundnut snack delicacy. These spices present a potent weapon in the arsenal of options available for drastically reducing the myco/entero toxin burden in Nigeria and other African countries where this food product is widely consumed. Other options that are applicable include, rapid drying of harvested groundnut to low safe moisture content before storage and growing crop varieties that have long durability in storage since most of the microbial growth and production of toxins are initiated and advanced in the pre-processing stages as shown by the results from the present study.

\section{COMPETING INTERESTS}

The authors declare that they have no competing interests.

\section{AUTHORS' CONTRIBUTIONS}

FA designed the study; team composed by FA and ATD carried out the studies, acquired and analyzed the data. FA drafted the manuscript and supervised the work and revised the final draft of the manuscript. Both authors read and approved the final manuscript.

\section{ACKNOWLEDGEMENTS}

Authors thank Mr. Nick Oyejide (Lab Technologist, Department of Biological Sciences, Redeemer's University) for support in the microbiology laboratory.

\section{REFERENCES}

Ademola SG, Shittu MD, Osanyande MO, Omidiji OE. 2015. Effects of Mycotoxin Detoxifier Supplementation to Contaminated Groundnut Cake on the Growth Performance, Organs and Serum Enzymes of Two Broiler Strains. International Journal of Agriculture Innovations and Research 4(2): 2872-34. DOI: http://ijair.org/administrator/component 
s/com jresearch/files/publications/IJAI

R_1545_Final.pdf

Adjou ES, Yehouenou B, Sossou CM. 2012.

Occurrence of mycotoxins and associated mycoflora in peanut cake product (kulikuli) marketed in Benin. African Journal of Biotechnology, 11(78): 14354. DOI: 10.5897/AJB12.324

Agbebi OT, Ilesanmi AI, Abdulraheem I. 2013. Additive potentials of Zingiber officinale on the aflatoxin secreted in wastemould feed fed to Clarias gariepinus (burchell, 1822). International Journal of Biological and Chemical Sciences, 7(1): 236-246. DOI: http://ajol.info/index.php/ijbcs

Ajayi JO. 2015. The paradox of poverty and inequality in Nigeria-insights for a post-2015 development agenda. Scientific Papers SeriesManagement, Economic Engineering in Agriculture and Rural Development, 15(3): 25-34. DOI: http://managementjournal.usamv.ro/pdf /vol.15 3/Art4.pdf

Aletor O, Ojelabi A. 2007. Comparative evaluation of the nutritive and functional attributes of some traditional Nigerian snacks and oil seed cakes. Pakistan Journal of Nutrition, 6(1): 99103. DOI: http:// www.docsdrive.com/pdfs/ansinet/pjn/2 007/99-103.pdf

Atanda O, Oluwabamiwo BF, Makun HA, Ogara IM, Idahor $\mathrm{KO}$, Eshiett $\mathrm{ME}$, Edema M. 2013. Fungal and mycotoxin contamination of Nigerian foods and feeds. INTECH Open Access Publisher. DOI: http:// dx.doi.org/10.5772/55664

Ayoade F, Osho A, Adesanya OO, Fayemi NE, Ojo GI. 2012. Effect of natural spices on the progression of microbial food spoilage in the steamed beans pudding, moin-moin. International Journal of Biological and Chemical
Sciences, 6(6): $\quad$ 5030-5041. DOI: http://ajol.info/index.php/ijbcs

Ayoade F, Fayemi SO, Daramola GG, Osho A, Oyejide NE, Adenodi SA, Anazodo KO. 2013. Effectiveness of storage as a point-of-use means of improving the bacteriological quality of drinking water. International Journal of Biological and Chemical Sciences, 7(1): $\quad$ 96-106. DOI: http://ajol.info/index.php/ijbcs

Bag A, Chattopadhyay RR. 2015. Evaluation of synergistic antibacterial and antioxidant efficacy of essential oils of spices and herbs in combination. PloS one, 10(7): $\quad \mathrm{e} 0131321$. DOI: http://dx.doi.org/10.1371/journal.pone. 0131321

Bankole SA, Adebanjo A. 2003. Aflatoxin contamination of dried yam chips marketed in Nigeria. Tropical science, 43(4): 201-203. Doi: $10.1002 /$ ts. 119

Benkeblia N. 2004. "Antimicrobial activity of essential oil extracts of various onions (Allium cepa) and garlic (Allium sativum)." LWT-Food Science and Technology 37(2): 263-268. Doi:10.1016/j.lwt.2003.09.001

Boli ZA, Zoue LT, Alloue-Boraud WM, Kakou CA, Koffi-Nevry R. 2014. Proximate composition and mycological characterization of peanut butter sold in retail markets of Abidjan (Côte d'Ivoire). Journal of Applied Biosciences, 72(1): 5822-5829.

Burt S. 2004. Essential oils: their antibacterial properties and potential applications in foods - a review. International journal of food microbiology, 94(3): 223-253. DOI:

http://dx.doi.org/10.1016/j.ijfoodmicro. 2004.03.022

Cox JM, Pavic A. 2010. Advances in enteropathogen control in poultry production. Journal of Applied Microbiology, 108(3): 745-755. Doi: 10.1111/j.1365-2672.2009.04456.x 
Cousin MA, Riley RT, Pestka JJ. 2005. Foodborne Mycotoxins:

Chemistry, Biology, Ecology, and Toxicology. Caister Academic Press: Norfolk, UK; 163-226

Cheesbrough M. 2006. District Laboratory Practice in Tropical Countries $\left(2^{\text {nd }}\right.$ edn). Cambridge University Press.

Cherrat L, Espina L, Bakkali M, García-Gonzalo D, Pagán R, Laglaoui A. 2014. Chemical composition and antioxidant properties of Laurus nobilis L. and Myrtus communis L. essential oils from Morocco and evaluation of their antimicrobial activity acting alone or in combined processes for food preservation. Journal of the Science of Food and Agriculture, 94(6): 11971204. DOI: $10.1002 /$ jsfa.6397

Ejoh SI, Ketiku OA. 2013. Vitamin E Content of Traditionally Processed Products of Two Commonly Consumed OilseedsGroundnut (Arachis Hypogea) and Melon Seed (Citullus Vulgaris) in Nigeria. Journal of Nutrition \& Food Sciences, 3(2): $\quad 1-5 . \quad$ DOI: http://dx.doi.org/10.4172/21559600.1000187

Eke-Ejiofor J, Kiin -Kabari DB, Chukwu EC, 2012. Effect of processing method on the proximate, mineral and fungi properties of groundnut (Arachis hypogea). Seed Journal of Agricultural and Biological Science 3: 257- 261.

Esimone CO, Nworu CS, Harrison GT 2010. Antibiogram and plasmid profile of some multi antibiotics resistant urinopathogens obtained from local communities in Southeastern Nigeria. Ibinosina J. Med.BS., 2(4): 152-159.

Ezekiel CN, Warth B, Ogara IM, Abia WA, Ezekiel VC, Atehnkeng J, Bandyopadhyay R. 2014. Mycotoxin exposure in rural residents in northern Nigeria: a pilot study using multiurinary biomarkers. Environment International, 66:

138-145. http://dx.doi.org/10.1016/j.envint.2014. 02.003

Ezekiel CN, Kayode FO, Fapohunda SO, Olorunfemi MF, Kponi BT. 2012. Aflatoxigenic moulds and aflatoxins in street-vended snacks in Lagos, Nigeria. Internet Journal of Food Safety, 14: 83-88.

Ezekiel CN, Oyinloye JMA, Fari AS, Omeonu AC, Akeredolu AA. 2011. Internet Journal of Food Safety. Internet Journal of Food Safety, 13: 175-181.

Ezekiel CN, Olarinmoye AO, Oyinloye JMA, Olaoye OB, Edun AO. 2011. Distribution, antibiogram and multidrug resistance in Enterobacteriaceae from commercial poultry feeds in Nigeria. Afr $J$ Microbiol Res, 5(3): 294-301. DOI: 10.5897/AJMR10.848

Frisvad JC, Larsen TO, De Vries R, Meijer M, Houbraken J, Cabañes FJ, Samson RA. 2007. Secondary metabolite profiling, growth profiles and other tools for species recognition and important Aspergillus mycotoxins. Studies in Mycology, 59: 31-37. DOI: http://dx.doi.org/10.3114/sim.2007.59. 04

Goncagul G, Ayaz E. 2010. Antimicrobial effect of garlic (Allium sativum) and traditional medicine. $J$ Anim Vet $A d v$, 9(1): 1-4.

Juglal S, Govinden R, Odhav B. 2002. Spice oils for the control of co-occurring mycotoxin-producing fungi. Journal of Food Protection, 65(4): 683-687.

Jimoh KO, Kolapo AL. 2008. Mycoflora and aflatoxin production in market samples of some selected Nigerian foodstuffs. Res J Microbiol, 3: 169-74.

Kolapo AL, Oladimeji GR, Ifejika AI, Osakine EO, Eyitayo IR, Oyelakin OA 2012. Aflatoxin, Nutritive Value and Microbiological status of stored cakes of some selected Nigerian oil seeds. Glob. J. Sci. Frontier Res. Agric Biol., 12(5): 1-10. 
Li R, Wang X, Zhou T, Yang D, Wang Q, Zhou Y. 2014. Occurrence of four mycotoxins in cereal and oil products in Yangtze Delta region of China and their food safety risks. Food Control, 35(1): $\quad$ 117-122. $\quad$ DOI: http://dx.doi.org/10.1016/j.foodcont.20 13.06 .042

Mbaeyi-Nwaoha IE, Egbuche NI. 2012. Microbiological evaluation of sachet water and street-vended yoghurt and "Zobo" drinks sold in Nsukka metropolis. International Journal of Biological and Chemical Sciences, 6(4): 1703-1717. DOI: http://ajol.info/index.php/ijbcs

Mutegi CK, Ngugi HK, Hendriks SL, Jones RB. 2012. Factors associated with the incidence of Aspergillus section Flavi and aflatoxin contamination of peanuts in the Busia and Homa bay districts of western Kenya. Plant pathology, 61(6): 1143-1153. Doi: 10.1111/j.13653059.2012.02597.x

Nejad ASM, Shabani S, Bayat M, Hosseini SE. 2014. Antibacterial effect of garlic aqueous extract on Staphylococcus aureus in hamburger. Jundishapur journal of microbiology, 7(11): e13134. Doi: $10.5812 /$ jjm. 13134

Odoemelam SA, Osu CI. 2009. Aflatoxin B1Contamination of Some Edible Grains Marketed in Nigeria. Journal of Chemistry, 6(2), 308-314. DOI: http://dx.doi.org/10.1155/2009/708160

Ogunyemi AK, Buraimoh OM, Onuorah NO, Ezeugwu SMC, Odetunde SK, Olumuyiwa EO. 2015. Bacteria associated with contamination of ready-to-eat (RTE) cooked rice in Lagos-Nigeria. International Journal of Biological and Chemical Sciences, 9(5): $\quad$ 2324-2333. DOI: http://ajol.info/index.php/ijbcs

Okaka JC 2005. Basic Processing of Grain Cereals and Legumes In Handling, Storage and Processing of Plant
Foods. OCJ Academic Publishers: Enugu, Nigeria; 30-60.

Okorondu SI, Akujobi CO, Nwachukwu IN. 2012. Antifungal properties of Musa paradisiaca (Plantain) peel and stalk extracts. International Journal of Biological and Chemical Sciences, 6(4): 1527-1534. DOI: http://ajol.info/index.php/ijbcs

Oladele D. 2014. The effects of aflatoxins on animals. Partnership for Aflatoxin Control in Africa (Meridian Institute, Washington, DC), Aflatoxin Partnership Newsletter, 2.

Panpatil VV, Tattari S, Kota N, Nimgulkar C, Polasa K. 2013. In vitro evaluation on antioxidant and antimicrobial activity of spice extracts of ginger, turmeric and garlic. Journal of Pharmacognosy and Phytochemistry, 2(3): 143-148. DOI:http://www.phytojournal.com/vol 2Issue3/Issue_sep_2013/39.1.pdf

Polixeni V, Panagiota M, 2009. Aflatoxin B1 and ochratoxin $\mathrm{A}$ in breakfast cereals from Athens market: Occurrence and risk assessment. Food Control 20(5): 455-461. DOI: http:// dx.doi.org/10.1016/j.foodcont.2008.07. 012

Redden B, Leonforte T, Ford R, Croser J, Slattery J. 2005. Pea (Pisum sativum L.). In Genetic Resources, Chromosome Engineering, and Crop Improvement, Singh RJ, Jahuar PP (eds). Taylor \& Francis: New York; 1: 49-83.

Ribeiro JMM, Cavaglieri LR, Fraga ME, Direito GM, Dalcero AM, Rosa CAR. 2006. Influence of water activity, temperature and time on mycotoxins production on barley rootlets. Letters in Applied Microbiology, 42(2): 179-184. DOI: $10.1111 / \mathrm{j} .1472-$ 765X.2005.01830.x

Richard JL, Payne GE, Desjardins AE, Maragos C, Norred WP, Pestka JJ. 2003. Mycotoxins: risks in plant, 
animal and human systems. CAST Task Force Report, 139: 101-103.

Ros E, 2010. Health benefits of nut consumption. Nutrients 2: 652 - 682 . Doi: 10.3390/nu2070652

Settaluri VS, Kandala CVK, Puppala N, Sundaram J. 2012. Peanuts and their nutritional aspects-a review. Food and Nutrition Sciences, 3(12): 1644. DOI: $10.4236 /$ fns. 2012.312215

Sibt-e-Abbas M, Butt MS, Sultan MT, Sharif MK, Ahmad AN, Batool R. 2015. Nutritional and functional properties of protein isolates extracted from defatted peanut flour. International Food Research Journal, 22(4): 1533-1537. DOI: http://www.ifrj.upm.edu.my/

Souza ELD, Lima EDO, Freire KRDL, Sousa CPD. 2005. Inhibitory action of some essential oils and phytochemicals on the growth of various moulds isolated from foods. Brazilian archives of Biology and Technology, 48(2): 245250. http://dx.doi.org/10.1590/S151689132005000200011

Speijers GJ, Speijers MH. 2004. Combined toxic effects of mycotoxins. Toxicology Letters, 153(1): 91-98. DOI: https://dx.doi.org/10.1016/j.toxlet.2004 .04 .046

Tajkarimi MM, Ibrahim SA, Cliver DO. 2010. Antimicrobial herb and spice compounds in food. Food control, 21(9): $\quad 1199-1218 . \quad$ DOI: 10.1016/j.foodcont.2010.02.003

Tiwari BK, Valdramidis VP, O’Donnell CP, Muthukumarappan $\mathrm{K}$, Bourke $\mathrm{P}$, Cullen PJ. 2009. Application of natural antimicrobials for food preservation. Journal of agricultural and food chemistry, 57(14): 5987-6000. Doi: $10.1021 / \mathrm{j} f 900668 \mathrm{n}$.

Watanabe T. 2010. Pictorial Atlas of Soil and Seed Fungi: Morphologies of Cultured Fungi and Key to Species, Third Edition. CRC Press. Taylor \& Francis Group. FL., USA. ISBN-10: 1439804192

Wendel AF, Brodner AH, Wydra S, Ressina S, Henrich B, Pfeffer K, MacKenzie CR. 2013. Genetic characterization and emergence of the metallo- $\beta$-lactamase GIM-1 in Pseudomonas spp. and Enterobacteriaceae during a long-term outbreak. Antimicrobial agents and Chemotherapy, 57(10): $\quad$ 5162-5165. Doi: 10.1128/AAC.00118-13 